\title{
TRPM8 ion channel in neuro-immune regulation of antigen binding function of spleen cells
}

\author{
Kozyreva TV ${ }^{1,2 *}$, Eliseeva LS $^{1}$, Khramova GM ${ }^{1}$, Voronova IP $^{1}$ and Evtushenko AA ${ }^{1}$ \\ ${ }^{1}$ Institute of Physiology and Basic Medicine, Timakov str. 4, Novosibirsk, 630117, Russia \\ ${ }^{2}$ Novosibirsk State University, Novosibirsk, Pirogov str. 2, Novosibirsk, 630090, Russia
}

\begin{abstract}
Ion channels, localized in cells with different specialization, may participate in the performance of various functions. In the experiments on rats, quantitative PCR has shown that spleen cells express the genes of thermosensitive TRP ion channels (TRPV1, TRPV2, TRPV3, TRPV4, TRPM8, and TRPA1). Experiments in vitro with the addition of an agonist of the TRPM8 ion channel menthol $\left(10^{-5} \mathrm{M}\right.$ and $\left.10^{-8} \mathrm{M}\right)$ to the incubation medium indicate the presence of the TRPM8 on immune cells, and its stimulatory effect on the antigen binding, the number of rosette-forming cells doubles under the influence of menthol at concentration of $10^{-8} \mathrm{M}$. Stimulation of the TRPM8 ion channel localized in the skin nerve afferents by menthol (1\% L-menthol) also has a stimulating effect on the antigen-binding function of spleen cells without interfering with the additional stimulation of this function when exposed to the TRPM8 agonist directly on spleen cells. The obtained results testify to the important role of the TRPM8 ion channel of different localization (in spleen cells and in the peripheral sensory neurons) in the regulation of the antigen binding function in the spleen. This indicates new moments of the neuro-immune interaction.
\end{abstract}

\section{Introduction}

Ion channels, localized in cells with different specialization, may participate in the performance of various functions. The TRP (transient receptor potential) channels can form homo- or heterotetramers and display a great diversity in the activation mode, ion selectivity and physiological function. Almost all TRP channels are permeable to calcium, with the permeability ratio of $\mathrm{Ca} 2+$ relative to $\mathrm{Na}+\left(\mathrm{P}_{\mathrm{Ca}} / \mathrm{P}_{\mathrm{Na}}\right)$ typically ranging from 0.3 to 100 [1]. TRP channels are involved in various sensory functions including chemo-, thermo- and mechanosensation [2]. The transient receptor potential cation channel, subfamily $\mathrm{M}$, member 8 (TRPM8) is a member within the subset of temperaturesensitive TRP channels and is the principal receptor involved in cold sensation [3-5]. Primary afferent neurons that express TRPM8 innervate the surfaces of the mammalian body, including skin, oral cavity, bladder, and lungs [5-7]. TRPM8 afferents in skin are involved in the regulation of central physiological functions, including body temperature regulation and cold behavior [8,9]. It has also been shown that vagal afferents from the proximal gastrointestinal tract express TRPM8 and respond to cold and icilin [10]. In this context, TRPM8 signaling is likely to contribute to visceral perception, but may also have potential effects in the regulation of inflammatory responses.

The involvement of this cold-sensitive ion channel TRPM8 in temperature sensitivity and in the thermoregulation of the organism under the influence of cold has been described in the works of several researchers [11-17]. There are also a few studies showing the effect of this TRPM8 ion channel activation on the formation and development of local inflammation [18], immune processes [19,20], including the level of pro-inflammatory cytokines [21]. The latest data were obtained through stimulation of the TRPM8 ion channel, localized in skin nervous endings. It remains unknown whether the ion channel TRPM8 presents on immune spleen cells and whether we can affect the function of these cells directly through this ion channel.
The purpose of this study was to elucidate the involvement of the TRPM8 ion channel in the formation of the antigen-binding function of spleen cells. In this regard, the following tasks were set to:

1) Identify the presence of the TRPM8 ion channel on spleen cells when examining the expression of the genes of thermosensitive TRP ion channels;

2) Elucidate the possibility of changing the antigen binding function of spleen cells when directly affecting them by the TRPM8 ion channel agonist menthol in vitro experiments. To do this, the antigen binding function of spleen cells obtained from intact and pre-immunized animals is to be investigated;

3) Compare the effect of the TRPM8 ion channel activation, localized in skin thermosensitive structures (menthol application to skin) with the effect of activation of this ion channel directly on spleen cells;

4) Elucidate, whether the preliminary activation of the TRPM8 ion channel in skin thermosensitive structures influences on the effect of direct stimulation of the TRPM8 in spleen cell on the antigen binding function.

\section{Methods}

Experimental animals. The experiments were performed on male Wistar rats weighing $200-250 \mathrm{~g}$ at room temperature of $22-24^{\circ} \mathrm{C}$. The

*Correspondence to: Kozyreva TV, Institute of Physiology and Basic Medicine, Timakov str. 4, Novosibirsk, 630117, Russia, Novosibirsk State University, Novosibirsk, Pirogov str. 2, Novosibirsk, 630090, Russia, E-mail: Kozyreva@physiol.ru

Key words: TRPM8 ion channel, gene expression, antigen binding, menthol, spleen cells

Received: April 08, 2019; Accepted: May 16, 2019; Published: May 20, 2019 
animals were kept in standard conditions with free access to water and food. All procedures on animals were carried out in accordance with the international rules of the European Community 1986/609 / EEC Directives and the Helsinki Declaration.

Sampling for PCR analysis. After the decapitation of the animals, the spleen was quickly removed onto a cold substrate. Samples (pieces of 200-180 mg) from the central part of the spleen were frozen with liquid nitrogen and stored at $-70^{\circ} \mathrm{C}$ until isolation of total RNA. The group of animals used for this assay was comprised of 10 rats.

Quantitative RT-PCR. The expression of the ion channel genes was verified through the quantitative RT-PCR method, described in detail earlier [22]. This method gives us the possibility to investigate different genes the expressions of which are varied significantly. Characteristics of primers used to quantify mRNA of thermosensitive TRP ion channels in rat spleen are shown in Table 1 . All the primers used in this assay were developed on the basis of the sequences published in the EMBL Nucleotide database and synthesized by Biosan (Novosibirsk, Russia). Expression of the studied genes is presented in number of copies per 100 copies of the housekeeping gene - peptidyl-prolyl cistrans isomerase A (Ppia). The impurity of genomic DNA in the samples under investigation with the maximum number of amplification cycles was not detected.

Antigen-binding function. It is known that on the membranes of T-lymphocyte there are receptors to the sheep erythrocytes CD2, which are involved in the activation of T-lymphocytes [23]. The presence of this receptor on the T-lymphocyte membrane is used in the method of the rosette forming cells count, thus, the number of activated by antigen T-lymphocytes. The number of rosette-forming (antigen binding) cells was calculated on 1000 cells in a suspension of spleen cells applying a known method, described in detail earlier [19,24].

In a suspension of spleen cells obtained from intact animals, the number of spontaneous rosettes was estimated, and in the suspension of spleen cells from the immunized animals, the number of immune rosettes was estimated. Immunization of animals was carried out with sheep erythrocytes (intraperitoneally $5 \times 10^{8}$ in $0.5 \mathrm{ml}$ of physiological solution). The animals were killed by rapid (1-2 sec) decapitation with the help guillotine, the immunized animals were killed on the $5^{\text {th }}$ day after the introduction of the antigen.

Application of menthol to skin. Non-temperature activation of the peripheral ion channel TRPM8 was carried out by application to skin of the abdomen $\left(25 \mathrm{~cm}^{2}\right) 1 \mathrm{ml}$ of a $1 \%$ suspension of L-menthol (menthol5-methyl-2- [1 methylethyl] cyclohexanol; Sigma) in physiological saline, the duration of the application was $20 \mathrm{~min}$. The control animals were exposed to a 20-minute application of $1 \mathrm{ml}$ of pure saline. Preliminary the removal of hair with scissors without any chemical drugs and painful irritation was carried out.

Activation of spleen cells with menthol in vitro. To detect the presence of the TRPM8 ion channel on spleen cells and evaluate the effect of this channel on the antigen binding function, the suspension of spleen cells from each animal was divided into 3 parts: 1) to a spleen cell suspension was added menthol (agonist of TRPM8) solution at a concentration of $10^{-5} \mathrm{M}$; 2) menthol at a concentration of $10^{-8} \mathrm{M}$; 3 ) control - solvent without addition of menthol. The group of animals used for this assay was comprised of 10 rats.

Statistical analysis. The data are presented as means \pm S.E.M. and were treated for significance by the Student's " $t$ " test for independent variables with the program "Statistica".

\section{Results}

Expression of the TRP ion channel genes in the spleen. The study showed that genes of both heat-sensitive (TRPV1, TRPV2, TRPV3, TRPV4) and cold-sensitive (TRPM8, TRPA1) ion channels are expressed in various degrees in spleen - the organ of immune system (Table 2). Attention is drawn to the rather high expression of the TRPV2 gene, tens, or even hundreds of times higher, than the expression of other TRP ion channels under study. This feature of TRPV2 was also noted in the brain structures $[22,25]$. This is apparently connected with the participation of this ion channel in the basic processes of vital activity of cells of different specializations.

Rosette formation when applying menthol to spleen cells in vitro. The presence of TRP ion channels in spleen cells points at their involvement in the functioning of these cells. One of the TRP ion channels presented in spleen cells is the cold-sensitive TRPM8, functioning in a range of physiological temperatures $\left(8-28^{\circ} \mathrm{C}\right)$, and therefore of great interest. Next, we consider the participation of this ion channel in providing one of immune cell functions, i.e. antigen binding, which in this study was estimated by the level of rosette forming cells in the intact animals (spontaneous rosettes) and after immunization of the animals (immune rosettes).

Spontaneous rosettes. When different concentrations of menthol $\left(10^{-5} \mathrm{M}\right.$ or $\left.10^{-8} \mathrm{M}\right)$ were added to the medium, the number of

Table 1. Characteristics of primers used to quantify mRNA of thermosensitive TRP ion channels in rat spleen

\begin{tabular}{|c|c|c|c|c|}
\hline Gene & Sequence & Anneal temperature $\left({ }^{\circ} \mathrm{C}\right)$ & PCR product size (bp) & Number of cycles \\
\hline $\operatorname{Trpv} 1$ & $\begin{array}{l}\text { F 5'-ATGGAGTCCACACCACACAAG } \\
\text { R 5'- TGAGCATGTTGAGCAGAAGG }\end{array}$ & 60 & 211 & 34 \\
\hline $\operatorname{Trpv} 2$ & $\begin{array}{c}\text { F 5'-CCAAGCCCCTCGTCAATGCCC } \\
\text { R 5'-GAGGTGAACATCCGCTCCATTCTCTAC }\end{array}$ & 60 & 131 & 29 \\
\hline $\operatorname{Trpv} 3$ & $\begin{array}{l}\text { F 5'-CATGTACCAACCAGCCTGAG } \\
\text { R 5'-GCGTGAGACCGTCATTGTT }\end{array}$ & 56 & 222 & 35 \\
\hline $\operatorname{Trpv} 4$ & $\begin{array}{l}\text { F 5'-TCTGGTCACCCTCCTGAATC } \\
\text { R 5'-CTTGCTCTCCTTGGACACCT }\end{array}$ & 63 & 298 & 36 \\
\hline Trpm 8 & $\begin{array}{l}\text { F 5'- GAAGCCCATTGACAAGCACAAG } \\
\text { R 5'-ACGAAGACCAGGGCATAGAG }\end{array}$ & 64 & 189 & 36 \\
\hline Trpal & $\begin{array}{c}\text { F 5'- TTTGGAAAAGCAGCACGAG } \\
\text { R 5'- TGGGTGGCTAATAGAACAATGTG }\end{array}$ & 66 & 193 & 37 \\
\hline Ppia & $\begin{array}{l}\text { F 5'-CCGACTGTGGACAACTCTAAT } \\
\text { R 5'-ACTTGAAGGGGAATGAGGAAA }\end{array}$ & 61.5 & 168 & 28 \\
\hline$T p h 1$ & $\begin{array}{l}\text { F 5'-GAAAGTATTTCGCAGAGCTGG } \\
\text { R 5'-GGCGTGGGTTGGGTAGAGTTTGTT }\end{array}$ & 62 & $\begin{array}{l}283 \text { with intron } \\
134 \text { without intron }\end{array}$ & 37 \\
\hline
\end{tabular}


spontaneous rosettes increased significantly (Figure 1, top), and when menthol concentration was low $\left(10^{-8} \mathrm{M}\right)$, the increase of rosettes was much more pronounced $(\mathrm{P}<0.01)$. As can be seen from Table 3 , spontaneous rosettes are formed mainly by small cells, lymphocytes. Rosettes formed by large cells and morulae (cells completely covered with erythrocytes) are practically absent. The stimulating effect of menthol on spontaneous rosettes was realized due to lymphocytes, small cells (Table 3).

Immune rosettes. The number of rosette-forming cells in the suspension of spleen cells obtained from immunized animals was as expectedly larger than that of cells in a suspension from unimmunized rats (Figure 1, bottom). The stimulating effect of menthol on the formation of immune rosettes was significantly expressed only when menthol was added in vitro at a low concentration $\left(10^{-8} \mathrm{M}\right)$, but not at a high one $\left(10^{-5} \mathrm{M}\right)$ (Figure 1, bottom). In the formation of immune rosettes, both small and large cells took part, and a certain number of morulae were also noted. The stimulating effect of a low concentration of menthol on immune rosettes was manifested in an increase in the number of rosettes formed by all types of cells. Particularly pronounced is the effect of menthol on increasing the number of morulae, their number increased by 3.5 times.

Rosette formation when applying menthol to skin. The application of menthol to skin without any additional influences also affects the functional properties of immune cells, in particular, stimulates antigen binding, earlier this was also noted [19]. This manifest itself in both spontaneous and immune rosettes (Figure 2). The effect of menthol application to skin is more pronounced for spontaneous rosettes (an increase in the number of rosettes by 4 times) in comparison with the effect on immune rosettes (an increase by 2 times). The increase in the number of rosettes when menthol is applied to skin for both spontaneous and immune rosettes occurs mainly due to small immune cells (lymphocytes), without participation of large cells and morulae (Table 4).

Table 2. The level of mRNA of thermosensitive TRP ion channel genes in the spleen of rats

\begin{tabular}{|l|l|l|l|l|l|l|l|}
\hline \multirow{2}{*}{ Rats } & $\begin{array}{l}\text { Ppia } \\
\text { mRNA } \\
(\mathbf{n g} / \boldsymbol{\mu l})\end{array}$ & \multicolumn{6}{|l|}{ Number of copies per 100 copies of Ppia mRNA } \\
\cline { 5 - 9 } & Trpa1 & Trpm8 & Trpv1 & Trpv2 & Trpv3 & Trpv4 \\
\hline $\begin{array}{l}\text { Wistar, } \\
(n=10)\end{array}$ & $6,2 \pm 0,89$ & $1,6 \pm 0,21$ & $0,86 \pm 0,26$ & $0,7 \pm 0,14$ & $189,2 \pm 37,53$ & $3,1 \pm 0,59$ & $0,2 \pm 0,09$ \\
\hline
\end{tabular}

Table 3. The effect of adding different concentrations of menthol to the culture medium of spleen cells on rosette formation

\begin{tabular}{|c|c|c|c|c|}
\hline Groups & Small cells & Big cells & Morulaes & Total \\
\hline \multicolumn{5}{|c|}{ Spontaneous rosettes } \\
\hline $\begin{array}{c}\text { Control, } \\
n=9\end{array}$ & $12.5 \pm 1.10$ & - & - & $12.5 \pm 1.01$ \\
\hline $\begin{array}{c}\text { Menthol } 10^{-5} \mathrm{M} \\
\mathrm{n}=9\end{array}$ & $17.0 \pm 2.25$ & $3.0 \pm 1.55$ & - & $20.5 \pm 1.15^{* * *}$ \\
\hline $\begin{array}{c}\text { Menthol } 10^{-8} \mathrm{M} \\
\mathrm{n}=9\end{array}$ & $23.0 \pm 1.35^{* * *}$ & $3.0 \pm 1.35$ & - & $26.5 \pm 1.50^{* * * *}$ \\
\hline \multicolumn{5}{|c|}{ Immune rosettes } \\
\hline $\begin{array}{c}\text { Control, } \\
\mathrm{n}=9\end{array}$ & $50.0 \pm 4.50$ & $20.0 \pm 2.65$ & $6.0 \pm 1.40$ & $76.0 \pm 2.30$ \\
\hline $\begin{array}{c}\text { Menthol } 10^{-5} \mathrm{M} \\
\mathrm{n}=9\end{array}$ & $39.0 \pm 3.10$ & $17.0 \pm 2.20$ & $11.5 \pm 1.45$ & $68.0 \pm 3.25$ \\
\hline $\begin{array}{c}\text { Menthol } 10^{-8} \mathrm{M} \\
\mathrm{n}=9\end{array}$ & $81.0 \pm 7.00^{* * *}$ & $30.5 \pm 3.25^{*}$ & $21.5 \pm 4.40^{*}$ & $135 \pm 6.40^{* * *}$ \\
\hline
\end{tabular}

Significant differences from control: ${ }^{*} \mathrm{P}<0.05 ;{ }^{* * *} \mathrm{P}<0.001$

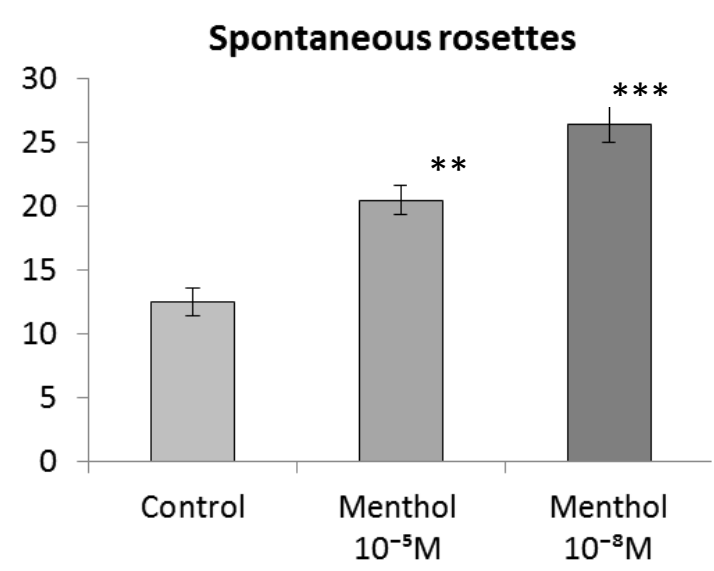

Immune rosettes

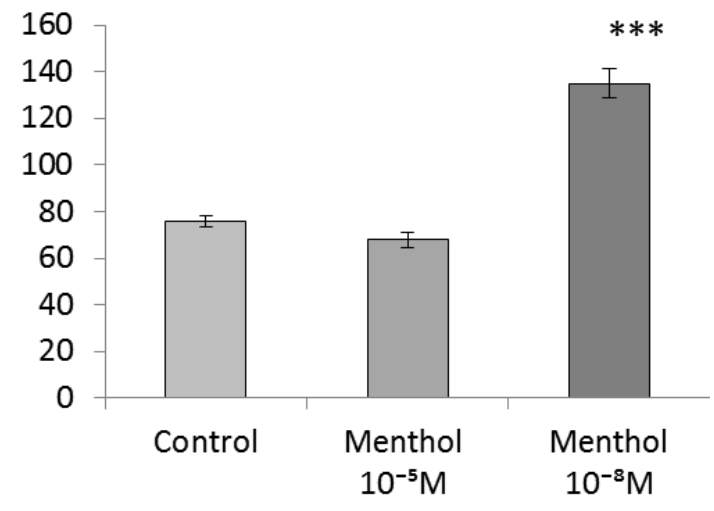

Figure 1. Influence of menthol (agonist of the TRPM8 ion channel) added to spleen cells in vitro on the antigen binding function. Spontaneous rosettes (top) - rosette forming cells from intact rats. Immune rosettes (bottom) - rosette forming cells from preliminary immunized rats. Axis of ordinates - the number of rosette forming cells per 1000 spleen cells. Control - spontaneous or immune rosette forming cells without menthol addition in vitro. Differences from control: ** $\mathrm{P}<0,01 ;{ }^{* * *} \mathrm{P}<0,001$

Table 4. Effect of menthol application to skin on rosette formation (antigen binding function) by different types of spleen cells

\begin{tabular}{|c|c|c|c|c|}
\hline Groups & Small cells & Big cells & Morulae & Total \\
\hline $\begin{array}{c}\text { Control, } \\
\mathrm{n}=9\end{array}$ & $12.5 \pm 1.10$ & - & - & $12.5 \pm 1.01$ \\
\hline $\begin{array}{c}\text { Application of } \\
1 \% \text { menthol to } \\
\text { skin } \\
\mathrm{n}=8\end{array}$ & $\begin{array}{c}36.5 \pm 2.80^{* * *} \\
(292 \%)\end{array}$ & $15.0 \pm 3.40$ & $11.2 \pm 2.90$ & $\begin{array}{c}54.5 \pm 1.50^{* * *} \\
(436 \%)\end{array}$ \\
\hline \multicolumn{3}{|c|}{ Immune rosettes } \\
\hline $\begin{array}{c}\text { Control, } \\
\mathrm{n}=9\end{array}$ & $32.5 \pm 2.05$ & $14.0 \pm 1.40$ & $11.0 \pm 1.50$ & $54.6 \pm 1.80$ \\
\hline $\begin{array}{c}\text { Application of } \\
1 \% \text { menthol to } \\
\text { skin } \\
\mathrm{n}=8\end{array}$ & $75.0 \pm 4.80^{* * *}$ & $24.5 \pm 3.05^{*}$ & $15.65 \pm 4.05$ & $115.0 \pm 2.50^{* * *}$ \\
\hline
\end{tabular}

Significant differences from control: ${ }^{*} \mathrm{P}<0.05 ;{ }^{* * *} \mathrm{P}<0.001$

Influence of menthol in vitro on rosette formation after the application of menthol to skin. Since the application of menthol to skin already caused the stimulation of antigen binding (Figure 2), there was the question whether addition of menthol in vitro would exert further influence. It turned out that in vitro the effect of menthol on 
spleen cells obtained from animals after the menthol application to skin was similar to the effect of menthol on the cells obtained from animals without pre-application of menthol to skin. Menthol at a concentration of $10^{-5} \mathrm{M}$ had no effect on rosette number, whereas menthol at a low concentration of $10^{-8} \mathrm{M}$ significantly increased the rosette formation (Figure 3).

\section{Spontaneous rosettes}

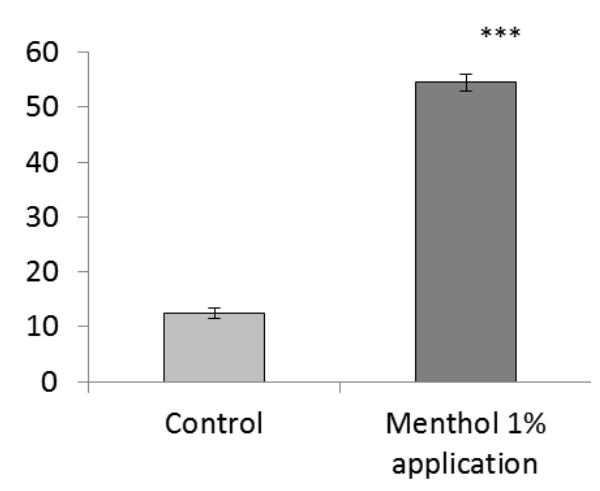

Immune rosettes

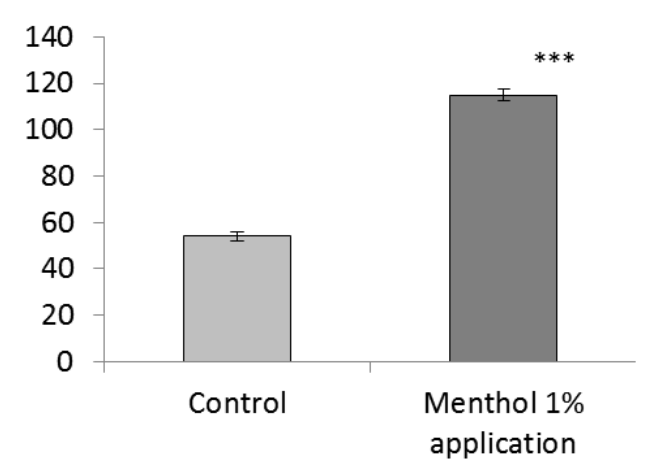

Figure 2. Effect of $1 \%$ menthol application to skin on the antigen binding function of spleen cells. Spontaneous rosettes (top) - rosette forming cells from intact rats. Immune rosettes (bottom) - rosette forming cells from preliminary immunized rats. Axis of ordinates - the number of rosette forming cells per 1000 spleen cells. Control - spontaneous or immune rosette forming cells without menthol application to skin. Differences from control: ${ }^{* * * *} \mathrm{P}<0,001$

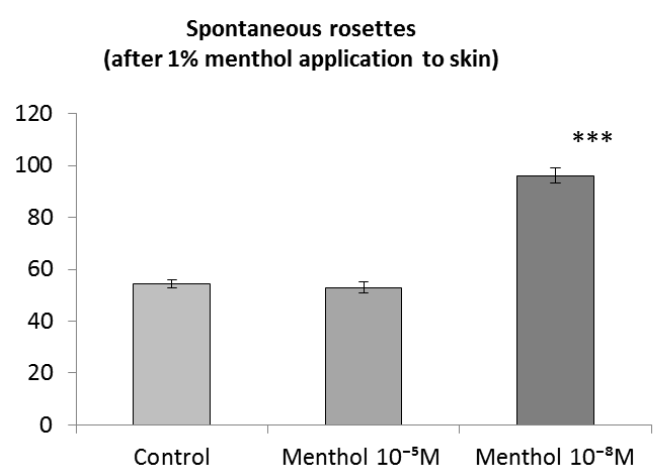

Figure 3. Influence of menthol added to spleen cells in vitro on the antigen binding function. Spontaneous rosettes - rosette forming cells from rats to which preliminary $1 \%$ menthol application to skin was performed. Axis of ordinates - the number of rosette forming cells per 1000 spleen cells. Control - spontaneous rosette forming cells without menthol addition in vitro. Differences from control: ${ }^{* * *} \mathrm{P}<0,001$

\section{Discussion}

The results obtained for gene expression indicate the presence of thermosensitive TRP ion channels on spleen cells, which is consistent with data on the sensitivity to temperature of various parameters of the immune response $[24,26,27]$. The presence of various cold- and warmsensitive ion channels indicates the possible effect of temperature in both cases - at cooling and heating.

Previously, we clearly showed that a decrease in body temperature to different degrees can cause different shifts in the immune response: shallow cooling with a decrease in body temperature by $1^{\circ} \mathrm{C}$ leads to stimulation of the antigen binding function, whereas deeper cooling depresses antigen binding [19,24]. Taking into account the obtained results, it can be connected with the function of different thermosensitive ion channels. The enhancement of the antigen binding function at shallow cooling seems to be due to the activation of the TRPM8 ion channel in skin, whereas inhibition of antigen binding in deep cooling may well be related to the functional properties of other ion channels, which, as the present results have demonstrated, are also present on spleen cells.

Experiments using the TRPM8 ion channel agonist in vitro indicate the presence of TRPM8 on immune cells and the involvement of this ion channel in the function of the lymphocyte receptors that recognize the antigen. The presence of the TRPM8 ion channel is typical for spleen cells of different types, since the activation of TRPM8 with menthol results in increased antigen binding by both small (lymphocytes) and large cells, which may include macrophages and plasmatic cells. The presence of TRPM8 on macrophages of pulmonary tissue is indicated in the studies of Khalil and his co-authors [28].

The stimulating effect of the TRPM8 ion channel activation on antigen binding for spontaneous rosettes is realized, mainly, due to lymphocytes. For immune rosettes obtained after prior immunization of animals, the effect of activation of the TRPM8 in vitro is observed not only for lymphocytes, but also for large cells, which may indicate an increase in the number of cells with TRPM8 ion channels under the influence of immunization, as well as increase in the expression of the TRPM8 ion channel. This can be confirmed by the increase in the number of morulae.

It should be noted that the stimulating effect is provided by a low concentration of menthol $\left(10^{-8} \mathrm{M}\right)$ a higher concentration $\left(10^{-5} \mathrm{M}\right)$ has less or no effect on the antigen binding function (Figure 1). This may be due to the possible effects of menthol at high concentration on other ion channels, such as TRPV 3 or TRPA1. In some studies, the possibility of the action of menthol on these ion channels was noted [29-32].

The application of the TRPM8 agonist menthol to skin also has a stimulating effect on the antigen binding function, as it was shown earlier by Kozyreva et al. [19] and confirmed in this study. If the TRPM8 activation directly on spleen cells increases spontaneous and immune rosette formations, approximately equally, then when this TRPM8 ion channel is activated in skin afferent nerves (when menthol is applied to skin), the effect on spontaneous rosettes is much more pronounced than on immune rosettes (Figure 2).

Consequently, the activation of the TRPM8 ion channel of different localization - on nerve endings in skin and directly on immune cells can lead to stimulation of antigen binding. At the same time, an increase in antigen binding by spleen cells after the TRPM8 activation in the nerve endings in skin does not prevent the additional enhancement of antigen binding under the activation of the TRPM8 directly on immune cells (Figure 3). 
The mechanisms of enhancing the antigen binding function upon the activation of the neuronal and non-neuronal TRPM8 are apparently different. It can be assumed that when stimulating of TRPM8 in nerve endings with menthol, similarly to the stimulation of this ion channel by cold, the activation of the sympathetic nervous system takes place, which in turn activates spleen cells. It is known that the activity of $\mathrm{T}$ cells is closely related to the activity of the sympathetic nervous system $[33,34]$, the increase in activity of the sympathetic system under the influence of cold is well known $[35,36]$ and the nerve fibers, on which the TRPM8 ion channel is localized, are those afferents that initiate all events associated with exposure to cold. The effect of menthol activated directly on spleen immune cells leads to stimulation of TRPM8, which is a calcium channel [11,37], provides entry into the cell of calcium ions, and can promote the activation of surface receptors binding antigens.

So, the data on gene expression testify to the presence of various thermosensitive TRP ion channels on spleen cells, which can be the molecular basis for the dependence of immune cell functions on temperature conditions. The shown presence of the TRPM8 ion channel in spleen cells is confirmed by data on the functional significance of this channel for antigen binding. Moreover, the ion channel TRPM8, localized in skin afferents, also has a modulating effect on the antigen binding function of spleen cells. It underlines the importance of the TRPM8 ion channel of different localization for the immune function of spleen cells. The stimulating effect of TRPM8 of peripheral afferent neurons on antigen binding does not prevent additional stimulation of this function when acting on this channel directly on spleen cells. This suggests the possibility of summation of unidirectional stimulating effects on antigen binding at activating the TRPM8 ion channel of different localization and indicates new moments of the neuro-immune interaction.

\section{Acknowledgement}

The work was performed in the frame of Basic Research Project of the Russian Federation N 0538-2014-0010.

\section{Conflict of interests}

The authors declare that there is no conflict of interests regarding the publication of this manuscript.

\section{References}

1. Nilius B, Owsianik G, Voets T, Peters JA (2007) Transient receptor potential cation channels in disease. Physiol Rev 87: 165-217. [Crossref]

2. Holzer P (2011) TRP channels in the digestive system. Curr Pharm Biotechnol 12: 24-34. [Crossref]

3. Brauchi S, Orio P, Latorre R (2004) Clues to understanding cold sensation: Thermodynamics and electrophysiological analysis of the cold receptor TRPM8. PNAS 101: 15494 -15499.

4. Dhaka A, Murray AN, Mathur J, Earley TJ, Petrus MJ, et al. (2007) TRPM8 is required for cold sensation in mice. Neuron 54: 371-378. [Crossref]

5. Dhaka A, Earley TJ, Watson J, Patapoutian A (2008) Visualizing cold spots: TRPM8expressing sensory neurons and their projections. J Neurosci 28: 566-575. [Crossref]

6. Hayashi T, Kondo T, Ishimatsu M, Yamada S, Nakamura K, et al. (2009) Expression of the TRPM8-immunoreactivity in dorsal root ganglion neurons innervating the rat urinary bladder. Neurosci Res 65: 245-251.

7. Fisher JT (2011) TRPM8 and dyspnea: from the frigid and fascinating past to the cool future? Curr Opin Pharmacol 11: 218-223. [Crossref]

8. Almeida MC, Hew-Butler T, Soriano RN, Rao S, Wang W, et al. (2012) Pharmacological blockade of the cold receptor TRPM8 attenuates autonomic and behavioral cold defenses and decreases deep body temperature. J Neurosci 32: 2086-2099. [Crossref]
9. Kozyreva TV, Voronova IP (2015) Involvement of Neurogenomic regulation in maintenance of temperature homeostasis in the cold. Russ $J$ Genetics: Applied Research 5: 569-576.

10. Zhang L, Jones S, Brody K, Costa M, Brookes SJ (2004a) Thermosensitive transient receptor potential channels in vagal afferent neurons of the mouse. Am J Physiol Gastrointest Liver Physiol 286: G983-G991.

11. Peier AM, Moqrich A, Hergarden AC, Reeve AJ, Andersson DA, et al. (2002) A TRP channel that senses cold stimuli and menthol. Cell 108: 705-715. [Crossref]

12. Dhaka A, Viswanath V, Patapoutian A (2006) Trp ion channels and temperature sensation. Annu Rev Neurosci 29: 135-161. [Crossref]

13. Bautista DM, Siemens J, Glazer JM, Tsuruda PR, Basbaum AI, et al. (2007) The menthol receptor TRPM8 is the principal detector of environmental cold. Nature 448: 204-208. [Crossref]

14. Kozyreva TV, Kozaruk VP, Tkachenko EY, Khramova GM (2010) Agonist of TRPM8 channel, menthol, facilitates the initiation of thermoregulatory responses to external cooling. J Thermal Biol 35: 428-434.

15. Kozyreva TV, Tkachenko EY, Khramova GM (2013) Effects of pharmacological activation of TRPM8 ion channels on the thermoregulatory responses during warming. Bull Exper Bio Med 155: 335- 338.

16. Tajino K, Hosokawa H, Maegawa S, Matsumura K, Dhaka A, et al. (2011) Coolingsensitive TRPM8 is thermostat of skin temperature against cooling. PLoS One 6: e17504. [Crossref]

17. Gavva CD, Davis C, Lehto SG, Rao S, Wang W, et al. (2012) Transient receptor potential melastatin 8 (TRPM8) channels are involved in body temperature regulation. Mol Pain 8: 36-41.

18. Jong PR, Takahashi N, Peiris M, Bertin S, Lee J, et al. (2015) TRPM8 on mucosal sensory nerves regulates colitogenic responses by innate immune cells via CGRP. Mucosal Immunol 8: 491-504.

19. Kozyreva TV, Khramova GM, Eliseeva LS (2012) The influence of TRPM8 ion channel activation on immune response at different temperature conditions. $J$ Thermal Biol 37: 648-653.

20. Kozyreva TV (2013) Participation of cold sensitive TRPM8 ion channel in modulation of metabolism and immune response. Front Immunol.

21. Kozyreva TV, Khramova GM, Voronova IP, Evtushenko AA (2016) The influence of cooling and TRPM8 ion channel activation on the level of pro-inflammatory cytokines in normotensive and hypertensive rats. J Thermal Biol 61: 119-124.

22. Voronova IP, Tuzhikova AA, Markel AL, Kozyreva TV (2015) Inherited stress-induced hypertension is associated with altered gene expression of thermosensitive TRP ion channels in hypothalamus. Journal of Experimental and Integrative Medicine 5: 149156

23. Roitt I, Brostoff J, Male D (1998) Immunology. Mosby International Ltd, London WCIH 9LB, UK, pp: 423.

24. Kozyreva TV, Eliseeva LS (2000) Immune response in cold exposures of different types. J Therm Biol 25: 401-404. [Crossref]

25. Kojima I, Nagasawa M (2007) TRPV2: A calcium-permeable cation channel regulated by insulin-like growth factors. In: Liedtke WB, Heller S, editors. TRP ion channel function in sensory transduction and cellular signaling cascades. Boca Raton (FL) CRC Press/Taylor \& Francis; Chapter 7.

26. Castellani J, Brenner I, Rhind S (2002) Cold exposure: Human immune responses and intracellular cytokine expression. Medicine Science in Sports Exercise pp: 2013-2020.

27. Cichoń M, Chadzińska M, Ksiazek A, Konarzewski M (2002) Delayed effects of cold stress on immune response in laboratory mice. Proc Biol Sci 269: 1493-1497. [Crossref]

28. Khalil M, Babes A, Lakra R, Försch S, Reeh PW, et al. (2016) Transient receptor potential melastatin 8 ion channel in macrophages modulates colitis through a balanceshift in TNF-alpha and interleukin-10 production. Mucos Immunol 9: 1500-1513.

29. Macpherson LJ, Hwang SW, Miyamoto T, Dubin AE, Patapoutian A, et al. (2006) More than cool: promiscuous relationships of menthol and other sensory compounds. $\mathrm{Mol}$ Cell Neurosci 32: 335-343. [Crossref]

30. Karashima Y, Damann N, Prenen J, Talavera K, Segal A, et al. (2007) Bimodal action of menthol on the transient receptor potential channel TRPA1. J Neurosci 27: 9874-84.

31. Vogt-Eisele AK, Weber K, Sherkheli MA, Vielhaber G, Panten J, et al. (2007) Monoterpenoid agonists of TRPV3. Br J Pharmacol 151: 530-540. [Crossref] 
32. Vriens J, Appendino G, Nilius B (2009) Pharmacology of vanilloid transient receptor potential cation channels TRPV. Mol Pharmacol 75: 1262-1279.

33. Besedovsky HO, Del Rey A (1996) Immune-neuro-endocrine interactions: facts and hypotheses. Endocr Rev 17: 64-102.

34. Eliseeva LS, Chramova GM, Gonsales EV, Kozyreva TV (2009) a1- andßadrenoblockers effects on immunogenesis in rats under thermoneutral conditions and after cooling of various extents. Bull Exp Biol Med 147: 208-212.
35. Depocas F, Behrens WA(1978) Levels of noradrenaline in plasma during thermogenesis induced by cold-exposure or by noradrenalina infusion in warm and cold-acclimated rats. In: Effect Thermogenesis. Basel-Stuttgart. pp: 135-146.

36. Kozyreva TV, Tkachenko EY, Kozaruk VP, Latysheva TV, Gilinsky MA (1999) Effects of slow and rapid cooling on catecholamine concentration in arterial plasma and the skin. Am J Physiol Regul Integr Comp Physiol 276: R1668-R1672.

37. Zhang L, Barritt GJ (2004) Evidence that TRPM8 is an androgen-dependent Ca2+ channel required for the survival of prostate cancer cells. Cancer Res 64: 8365-8373.

Copyright: $(02019$ Kozyreva TV. This is an open-access article distributed under the terms of the Creative Commons Attribution License, which permits unrestricted use, distribution, and reproduction in any medium, provided the original author and source are credited. 